\title{
Financing Long-Term Care: An Intragenerational Social Insurance Model
}

\author{
by Yung-Ping Chen*
}

\section{Introduction}

Financing long-term care has become an increasingly significant public policy challenge because of a confluence of factors. These factors juxtapose the expanding numbers of older people, particularly the very old, against the public and private resources that are growing at a much slower rate. This article proposes a new paradigm - the use of an intragenerational social insurance program I call "Social Security/Long-Term Care" to provide a basic level of long-term care protection.

Traditional pay-as-you-go social insurance programs, such as Social Security and Medicare, are built on the bedrock of intergenerational transfers. This works well when the population and economy are growing to the extent that, over a long period of time, taxes paid by workers and their employers are rising faster or at least keep pace with benefit payments to retirees and other beneficiaries. At this time, however, these programs are showing financial strain as a result of population aging and slow economic growth.

In contrast, the Social Security/Long-Term Care plan I suggest is an intragenerational social insurance model. In my plan, Social Security beneficiaries are the ones who are financing their own basic level of long-term care protection by transfering part of their Social Security benefits to pay for it. This plan will not require additional intergenerational transfers.

Although this proposal is suggested for the United States, the underlying concept is relevant to other industrialized nations because they share many of the demographic and economic forces influencing social policy in general, and long-term care policy in particular.

In what follows, I list some of the major demographic and economic developments that shape the context in which financing for long-term care is being considered. Next, I identify the inadequacy of the current pattern for financing long-term care costs and suggest a plan called, "Social Security/Long-Term Care", which is an intragenerational social insurance model. Finally, I present the advantages of the proposed paradigm over using the conventional intergenerational social insurance model for long-term care.

* Yung-Ping Chen, Ph. D., is the Frank J. Manning Eminent Scholar's Chair in Gerontology at the University of Massachusetts Boston, U.S.A. He gratefully acknowledges comments and suggestions by Stephen C. Goss and Donna Polisar. 


\section{Major demographic and economic developments}

\subsection{The continued greying of America and the growth of the very old}

Those aged 65 and older, numbering 31.2 million or 12.5 percent of the population in 1990 , are estimated to grow to 52 million or 17.7 percent of the population in 2020 . Those aged 85 or over are projected to more than double from 3.1 million in 1990 to 6.5 million in 2020 (Vladeck, Miller and Clauser, 1993). Although a recent study suggests that the prevalence of chronic disability in older persons declined during the 1980s (Manton, Corder and Stallard, 1993), the growth in absolute numbers of those persons aged 65 and over, particularly of the very old, is likely to have a greater effect on their need for long-term care than the reductions in age-specific disability rates.

The need for home care and nursing home care is already considerable. Currently, 4.7 percent of the U.S. population or 12.6 million people ( 7.3 million elderly and 5.3 million nonelderly, including 500,000 children) need long-term care services. The vast majority, 82 percent or 10.3 million of them, live in the community, with 18 percent or 2.3 million staying in nursing homes (Vladeck, Miller and Clauser, 1993).

\subsection{Relative shrinkage of informal caregivers}

Much of the care for the disabled is provided at home by unpaid family members and friends. This category of people are known as informal caregivers, most of whom are adult children and spouses; not surprisingly a great majority of them are women (see, for example, Stone, Cafferata and Sangl, 1987). This potential pool of informal caregivers is declining, however, due to increasing proportions of women entering the paid labor force and lower fertility rates which produce smaller families.

\subsection{Declines in rates of productivity growth and national savings}

In the two decades between 1970 and 1990, the productivity of American workers grew at the rate of 1.3 percent per year, a rate far below the average annual growth rate of 3.4 percent during the previous 20 years, 1950 to 1969 . The net national savings rate in the $1980 \mathrm{~s}$ was an annual average of 3.6 percent of the gross domestic product, compared to an average of 9.8 percent per year in the 1960s (based on data in the Council of Economic Advisers, 1994). Consequently, the economic growth rate has slowed and so has the rate of increase in the financial capability of both private and public sectors.

\subsection{Accumulating federal deficits and national debts}

In the 1980s, annual federal budget deficits averaged approximately $\$ 150$ billion per year. The national debt now stands at more than $\$ 4.5$ trillion and continues to rise, albeit at a slower rate (based on data in the Council of Economic Advisers, 1994). This fiscal stringency virtually precludes funding for new programs that could deal with social problems.

Together, the aforementioned trends imply a complex set of issues in designing ways to protect against long-term care risk when resources are growing more slowly. This fiscal environment may provoke concerns over intergenerational equity or the potential for generational conflicts.

\section{Problems with current pattern for financing long-term care}

Long-term care is a risk that may carry with it substantial and even catastrophic financial consequences. Nevertheless, this risk happens to only a small and predictable proportion 
of the population at any one time. In theory, then, the ideal mechanism for protecting against this type of contingency is insurance. In practice, however, private out-of-pocket payment and Medicaid are each defraying nearly half the total formal long-term care costs, with Medicare and private long-term care insurance policies, combined, covering the remaining five percent. Private out-of-pocket payment fails to utilize insurance protection, while Medicaid requires near-exhaustion of income and assets for eligibility. These financing methods are destabilizing and unsustainable because they tend to impoverish many people and increasingly strain government budgets.

Paying for long-term care in this way is like sitting on a stool with only two legs. I suggest, instead, a three-legged stool approach in which insurance - both social insurance and private insurance - will assume a more significant role. Paying premiums to buy private insurance policies and paying taxes (like premiums) for a social insurance program are a more economically efficient method to meet the costs of long-term care, rather than shouldering the bills themselves. Furthermore, because public and private resources are increasingly more in demand for various purposes, I suggest the concept of "tradeable benefits", under which one type of benefit (e.g., Social Security cash payments) may be exchanged for another (e.g., long-term care coverage).

\subsection{Existing three-legged stools}

The idea of a three-legged stool is hardly radical. It is patterned after the way we provide retirement income and acute health care for older people. Reflecting shared private and public responsibilities, retirement income is provided using Social Security for a floor of protection, occupational pensions and personal savings for additional income, and Supplemental Security Income for a safety net. Similarly, acute health care for older persons is provided by Medicare for basic coverage, which is supplemented by employerprovided retiree health benefits and individual payments for noncovered expenses (including Medigap policies); and Medicaid serves as a safety net. In such a way, a threelegged stool for long-term care could begin with a new basic coverage using social insurance. This protection could then be supplemented with private long-term care insurance and personal income and savings. Medicaid will be restored to its original purpose of helping the poor.

\subsection{The proposed social security/long-term care plan}

The cornerstone of this approach is a social insurance program for providing basic coverage for long-term care, similar to Social Security which was designed to provide a floor of income protection. How is this program to be financed? In a simpler world, taxes could be raised. However, in the current milieu, where resistance to taxes is high, I suggest that we consider trading a small percentage of Social Security cash benefits for basic long-term care coverage. I call this trade-off plan "Social Security/Long-Term Care".

The concept of tradeable benefits is admittedly unconventional. However, without much prospect for any increase in taxes, a trade-off plan might be the only way in which people would set aside a portion of retirement income for their long-term care needs through insurance. I estimate that by trading five percent of Social Security cash benefits we could finance a basic amount of long-term care coverage through social insurance. Such a trade-off would exempt low-income people. In 1994, one percent of Social Security benefits is equal to approximately $\$ 3.2$ billion. A five percent trade-off would generate $\$ 16$ billion. 
Social Security/Long-Term Care could be supplemented with private long-term care insurance policies; premiums for them would be paid from current income and/or savings. However, if out-of-pocket payments were unavailable for the supplemental private insurance, then, applying the same trade-off principle, it should be possible to link private longterm care insurance to occupational pensions and/or to savings vehicles, such as Individual Retirement Accounts, Keogh plans, and the like that are already in place. The basic social insurance program could be enacted first, and be followed by private insurance programs.

\section{Coverage under Social Security/Long-Term Care}

As indicated earlier, a five percent trade-off would generate approximately $\$ 16$ billion in 1994. That amount would be sufficient to cover an estimated 22 percent of the formal long-term care costs that year. Actuarial estimates suggest that the five percent Social Security/Long-Term Care plan could be expected to provide nursing home coverage of one year at 85 percent of customary and reasonable charges after a 90 -day waiting period (Chen, 1993). Alternatively, it could finance home care coverage for approximately two years.

It would be best to phase in a Social Security/Long-Term Care plan by establishing a substantial contingency reserve fund that could meet unexpectedly high expenses. Such a reserve would allow time to modify the plan in response to any adverse actual cost, without much disruption. The creation of such a reserve fund may be accomplished as follows.

The new plan could be implemented with a Long-Term Care Trust Fund in the same manner as the trust funds for Social Security and for Medicare. Let's assume that the Social Security/Long-Term Care would become law in January 1996 and would build up a trust fund using the increase in the cost-of-living adjustments (COLA) to phase in the system, as described below.

The new plan would specify that all Social Security retirees, except those exempted due to low income, were required to pay one percent of their Social Security benefits into the Long-Term Care Trust Fund beginning January 1, 1996. Each year their rate would rise by one percentage point to the ultimate level of five percent, beginning January 1,2000 and for all years after. Long-term care coverage would begin January 1, 2001, adopting Social Security as a precedent ; Social Security started collecting payroll taxes on January 1, 1937 and did not begin paying the monthly benefits until January 1, 1940.

Table 1 shows the estimated annual revenue and accumulated trust fund levels for the first five years of operation. The total amount of the Long-Term Care Trust Fund at the end of 2000 would be approximately $\$ 69$ billion, using intermediate assumptions (in the 1993 Annual Trustees Report) on Social Security benefit amounts and on interest rates projected for 1996 though 2000. The annual revenue credited to the Long-Term Care Trust Fund is assumed to be invested in special-issue securities from the United States Treasury Department, as is currently and historically the case for the Social Security and Medicare Trust Funds.

\section{Why an intragenerational model?}

If a new program for long-term care is to be patterned after the traditional, intergenerational social insurance model as used by Social Security and Medicare, then some increase in the payroll tax will be required. Suppose the increase is only one percent of taxable payroll each for employec and employer, this new program will raise the total payroll tax for Social Security and Medicare by about one-tenth, as the following explanation makes clear. 
Table 1:

Estimated revenue for the proposed Long-Term Care (LTC) Trust Fund in first 5 years of operation (no disbursements)

(All dollar amounts are in billions)

\begin{tabular}{|c|c|c|c|c|c|}
\hline \multirow{2}{*}{$\begin{array}{l}\text { Calendar } \\
\text { year }\end{array}$} & $\begin{array}{c}\text { Social Security } \\
\text { (OASDI) } \\
\text { benefit payments }\end{array}$ & \multicolumn{2}{|c|}{$\begin{array}{c}\text { Annual contributions to } \\
\text { the LTC Trust Fund }\end{array}$} & \multirow{2}{*}{$\begin{array}{c}\text { Interest rate for } \\
\text { contributions } \\
\text { in the year }\end{array}$} & $\begin{array}{c}\text { LTC Trust Fund } \\
\text { accumulated at } \\
\text { the end of the year }\end{array}$ \\
\hline 1996 & $\$ 355.0$ & $1 \%$ & $\$ 3.6$ & $6.0 \%$ & $\$ 3.7$ \\
\hline 1997 & $\$ 374.9$ & $2 \%$ & $\$ 7.5$ & $6.0 \%$ & $\$ 11.7$ \\
\hline 1998 & $\$ 396.1$ & $3 \%$ & $\$ 11.9$ & $6.1 \%$ & $\$ 24.7$ \\
\hline 1999 & $\$ 419.0$ & $4 \%$ & $\$ 16.8$ & $6.3 \%$ & $\$ 43.5$ \\
\hline 2000 & $\$ 444.2$ & $5 \%$ & $\$ 22.2$ & $6.4 \%$ & $\$ 69.1$ \\
\hline
\end{tabular}

Note: OASDI benefits and interest rates are those projected under the alternative II (intermediate) assumptions in the 1993 Annual Report of the Trustees.

For Social Security (Old-Age, Survivors, and Disability Insurance or OASDI) and Medicare (Hospital Insurance or HI), currently, an employee pays 6.20 percent of taxable payroll for OASDI and 1.45 percent for $\mathrm{HI}$, for a total of 7.65 percent, which is matched by the employer.

Under the intermediate assumptions, OASDI is estimated to have a long-range deficit of 2.13 percent of taxable payroll (Public Trustees of the Social Security and Medicare Boards of Trustees, 1994). Defined as a 75-year period, the long-range for 1994 is from 1994 through 2068. In order that benefits now scheduled under the law will be paid in full, this deficit may be removed if the employee and employer payroll tax rates for OASDI are each raised to 7.265 percent from the current rate of 6.20 percent, for each year from 1994 through 2068 . HI is likewise faced with a long-range deficit, estimated at 4.14 percent of taxable payroll, under the intermediate assumptions (Public Trustees of the Social Security and Medicare Boards of Trustees, 1994). This deficit may be removed by adding 2.07 percent of taxable payroll to the current rate of 1.45 percent for $\mathrm{HI}$ for a total of 3.52 percent, paid by the employee and matched by the employer. In other words, if the long-range actuarial deficit of OASDI and $\mathrm{HI}$ is to be removed by increasing payroll tax rates, then employee and employer each would be paying a total of 10.785 percent of taxable payroll in each of the 75 years.

Any increase in the payroll tax for long-term care will add to the transfer from the working generation to the retired generation, which some may consider as burdensome or even unacceptable. Thus, as an intragenerational model, the Social Security/Long-Term Care Plan is suggested as a new paradigm for the retirees to pay for their own needs. Fundamentally, the plan I propose illustrates how to finance long-term care for ever-increasing numbers of older people when the means required is becoming scarcer, while avoiding the possibility of generational conflicts over this issue. 


\section{REFERENCES}

CHEN, Y. P. (1993): "A Three-Legged Stool: A New Way to Fund Long-Term Care", Care in the Long-Term: In Search of Community and Security. Institute of Medicine, National Academy Press. Washington, D.C. 54-70.

Council of Economic Advisers (1994): Annual Report. Washington, D.C., U.S. Government Printing Office.

MANTON, K.G., CORDER, L.S. and STALLARD, E. (1993): "Estimates of Change in Chronic Disability and Institutional Incidence and Prevalence Rates in the U.S. Elderly Population from the 1982, 1984, and 1989 National Long-Term Care Survey", Journal of Gerontology: Social Science, 48(4), SI53-SI66.

Public Trustees of the Social Security and Medicare Boards of Trustees (1994): Status of the Social Security and Medicare Programs: A Summary of The 1994 Annual Reports, Washington, D.C., U.S. Government Printing Office.

STONE, R., CAFFERATA, G., and SANGL, J. (1987): "Caregivers of the Frail Elderly: A National Profile". Rockville, MD, National Center for Health Services Research.

VLADECK, B.C., MILLER, N.A., and CLAUSER, S. B. (1993): "The Changing Face of LongTerm Care", Health Care Financing Review, 14 (4) (Summer), 5-23. 